\title{
Marketing and Government Policy on MSMEs in Indonesian: A Theoretical Framework and Empirical Study
}

\author{
Ernani Hadiyati ${ }^{1}$ \\ ${ }^{1}$ Economic and Business Faculty, Gajayana University, Malang, Indonesia \\ Correspondence: Ernani Hadiyati, Lecturer of Economic and Business Faculty, Gajayana University, Malang, \\ Indonesia. Tel: 62-812-358-4748. E-mail: ernani_hadiyati@yahoo.com
}

Received: October 23, 2014

Accepted: December 17, 2014

Online Published: January 20, 2015

doi:10.5539/ijbm.v10n2p128

URL: http://dx.doi.org/10.5539/ijbm.v10n2p128

\begin{abstract}
Marketing is the fundamental challenge faced by Small Medium Enterprises (MSMEs) to succeed. The most dominant issues SMEs have to deal with are: market and product competition, institution and market information access that supports marketing. To minimise the marketing problems, the government role as a policy maker is required, such as Act no. 20 year 2008 about MSMEs and the formation of Cooperation Ministry and Micro Small Medium Enterprises with marketing deputy. The government programme on small enterprise development and empowerment through strategical marketing planning formulation covers: export market expansion and development, marketing infrastructure development, marketing partnership expansion with established enterprises, product marketing network development and product promotion development. Government intervention in marketing is anticipated to conduce improving MSMEs performance that contributes to the national economic growth through PDB growth, employment, and non-oil export.
\end{abstract}

Keywords: marketing, marketing strategy, government policy, economic growth, MSMEs

\section{Introduction}

Empowerment of Micro, Small and Medium Enterprises (MSMEs) is an integral part of national development, aimed at building a just and prosperous society. In the economic development sector, the 1945 Constitution stresses explicitly the implementation of the kinship principle (Article 33, paragraph 1) and the implementation of the national economy, based on economic democracy (Article 33, paragraph 4).

Policies that supports the MSMEs (affirmative policy), has become a widespread expectation within the public, they are aware and concern about their fate of the publics' economy. Therefore, in addition to growth and economic stability, the greatest issue in the process of economic development today and in the future is the independence of the national economy and the equitable distribution of national development.

Hadiyati (2009, p. 2) explains that the success of MSMEs to struggle in the economic crisis does not make them able to develop properly. Many factors affect the slow progress of these efforts, among others, the lack of attention from the government that can help solving the existing problems. From the survey, SMEs has several common problems such as: low capital, difficulty in marketing the product, strong market competition, difficulty in obtaining raw material, lack of knowledge in the management and technical production.

In this case, the empowerment of MSMEs has a direct relation and improvement to the life as well as the welfare of the majority of Indonesian (pro-poor); in addition, the potential and the strategic role of MSMEs has proved to be a pillar of strength of the national economic growth (pro-growth). MSMEs as the dominant national economic actors is also a vital subject in development, especially in the context of the expansion of opportunities for new entrepreneurs, provide employment to reduce unemployment (pro job), as well as pro-environment (Ministry of Cooperatives and Micro Small \& Medium Enterprises, 2012). It is expected that the government and society devotes considerable attention to encourage its development. Development of MSMEs through the business empowerment approach, requires special attention to the social and cultural aspects of each region, because MSMEs is grown well in the middle of society. In addition, establishing mutual cooperation between MSMEs with large industrial through a partnership will also strengthen the structure of the national and regional economy. Participation of related parties or other stakeholders need to be continued; therefore, in the near future MSMEs can give valuable contribution in the national economy. But in the midst of the government's development efforts, 
the majority conditions of MSMEs are not ideal, where MSMEs are not experiencing significant growth and are not much different when the initial condition was established. Only a few MSMEs are capable of developing into large business. That is because SMEs has limitations and constraints (Sulistiyono \& Mulyanan, 2010). One of the weaknesses and constraints of MSMEs in order to achieve business success is the marketing aspect.

Marketing is considered relevant for both large and small organizations (Hogarth-Scott et al. 1996) and the basic principles of marketing is deemed applicable to both (Reynolds, 2002; Siu \& Kirby, 1998). Marketing in a small companies has unique characteristics that distinguish them from large organizations (Fillis, 2002; Gilmore et al., 2001). Marketing in a small company has been characterized by attributes such as haphazard, informal, loose, unstructured and spontaneous (Gilmore et al., 2001), and when it is compared to "textbook" of marketing seems to have negative connotations. Small companies seem to have certain disadvantages associated with pricing, planning, training and forecasting (McCartan-Quinn \& Carson, 2003). Most marketing in SMEs is driven by innovation (O’Dwyer et al., 2009). In addition, small companies appear to operate close to the customers, their purpose are to be flexible and to respond quickly to the changing customer needs (McCartan-Quinn \& Carson, 2003). Some SMEs place a strong emphasis on the customer service, concern with the employee welfare and reliance on intuition and environmental awareness in its marketing (Blankson et al., 2006). Another distinctive characteristic of small enterprise is that there are various constraint on marketing sector. According to the literature, the function of marketing in SMEs does not work well because of poor cash flow, lack of marketing expertise, the size of the business, tactical and strategic customer problems (O'Dwyer et al., 2009), a narrow customer base, excessive reliance on owner-managers marketing competencies (Stokes, 2000b), limited resources related to the finance and marketing concepts.

\section{Marketing on Micro, Small, and Medium Enterprises (MSMEs)}

Nowadays, the market is very competitive, it is marked by the speed and change as a common characteristic. Customers expect more new features and updates of existing products on a regular basis. The emergence of new technologies affect the way of doing business and raises the possibility of new markets. Hadiyati $(2010$, p. 13) explains that marketing is a fundamental problem which is faced by MSMEs; there are three things which is considered as a main problem, namely: the problem within competition of market and products, access to market information and institutions which supports the marketing of MSMEs.

The company must have the ability to constantly keep up with change and update the way running the business. It is important to encourage companies to become a player in the market when the companies launch their product because the knowledge of market is absolutely necessary and it separates the winners from the losers in the business. Market approach is required to gain the essential market knowledge to sell the product into the market. Market knowledge is very important, especially for micro and small businesses, because it helps in identifying other existing actors on the market that will become potential threat to its existence. Market knowledge also helps small businesses to develop a competitive advantage through improving customer knowledge and demand, and thus take a strong position in the market. Marketing of SMEs is based on the inherent characteristics of SMEs, such as, size, few number of resources, the influence the owner-behavior, strong sales focus, a strong awareness of some aspects of formal marketing, and personal contacts network. (Jovanov \& Stojanovski, 2012).

Watson (2003), states that the SMEs needs external support in the term of outsourcing, especially in the form of knowledge and information related to different aspects of enterprise function (management, finance, marketing, production, etc.).

The problem in general, such as the inability of entrepreneurs which leads to inadequate planning, sales and competitive weaknesses (identified as the most important factor of the failure of SMEs). Small companies generally have a lack of knowledge and skill in managerial and marketing aspects. This finding is supported by studies in the economics of two different countries, England and Nigeria (Ugwushi, 2009, p. 204). There are ten aspects which influence the general condition of business, namely disasters and accidents, competition, inadequate infrastructure and lack of social support, high taxes, lack of knowledge of accounting, managerial incompetence, poor marketing and sales efforts, poor economic conditions, inadequate planning of operations, financial problems. In England, the influential aspects are the managerial incompetence (77\%), poor marketing and sales efforts (69\%) and inadequate planning of operations, (88\%); while in Nigeria, the lack of knowledge and skill in managerial and marketing aspects are also critical factor to the success or failure in business - the managerial incompetence (44\%), poor marketing and sales efforts $(70 \%)$ and inadequate planning of operations $(50 \%)$. The success in small business depends not only on the presence of products and markets, but also the benefit of the marketing of products in the market (Smith, D., 1990, pp. 37-60). 
In the global recession, SMEs needs to be very proactive in keeping up the sales turnover. The basic principles of marketing apply to large and small businesses equally, the lack of sophisticated marketing is considered to be a problem for small companies. However, the Internet is now regarded as one of the marketing tools that can be used to allow small companies to effectively compete with large business organizations. Online marketing arena has experienced significant growth over the past few years, while traditional marketing has deteriorated mainly due to high costs. Small enterprises usually have different requirements in the marketing strategy, with the inherent characteristics which has an impact on the willingness or ability of the owner or manager to use conventional and or contemporary marketing tools (Cromie, 1991, p. 3).

The improvement of marketing skills in small businesses can be achieved through education on the owners or managers of SMEs. Marketing education, especially for the owner or manager of small enterprise is inherently problematic. These problems must be recognized and addressed by educators in marketing, which seeks to use education as a means to improve the marketing practices of small enterprises. Omar and Anas (2014) explain the results of their study that the general problems faced by SMEs are financial capital, management, production, skilled labor, marketing, quality, competition, support and other related problems. Abdullah (1997), also argues that the main problems faced by SMEs as a whole are capital problem, marketing, management, production, skilled labor, and so on. In addition, the findings Chamhuri et al. (1995) finds that the MSME entrepreneurs also face problems in terms of selling price. This problem exists because of the high cost of the production process and the number of the production produced by SMEs is too small, and therefore they cannot compete with large competitors. According to Chee (1985), there are various problems faced by SMEs. Among the major problems encountered is the competition for the domestic market and abroad. For the domestic market, the competition comes from the SMEs themselves and also from large -scale industrial operators of local and overseas. For overseas markets, Chee (1985) estimates that only 5 percent of the products of rural SMEs have been able to penetrate in the market. This situation may be due to lack of information or the high price and low quality. Ragayah and Rahmah (1995) conducts a study on the marketing and SME chain. In their study, there are important problems faced by SMEs who market the product. Low quality makes the manufacturers difficult to sell their product in the market, especially overseas. Although the company can produce the goods according to the desired output, they also have to take into account other things such as date line of supply and placing reasonable selling prices so that existing customers continue to buy from them. In addition to manage those problem under control, there are also problems, which beyond the control of the operator, such as late payments from buyers which will limit capital turnover and high transportation costs which can lead to high prices.

Ragayah and Mercy (1995), states that a good marketing strategy is closely related to the size of the different marketing channels, finding marketing channels as well as the affordable price. In addition, some aspects such as research, knowledge and experience about the price, competition, demand and consumer tastes are also important. Omar and Anas (2014) explains that in order to improve the marketing of SMEs, they need financial support and non-financial programs through partnerships with large companies in exploiting the marketing opportunities and carry out promotional activities for domestic and overseas market through branding and other promotional media. The partnership program which is conducted by linking SMEs with large companies and multi-national companies linked to the government needs to be improved. The finding of their research results that support of the government to MSMEs has a major impact to overcome the encountered problems. The partnership marketing which is conducted by SMEs is considered to be the best method.

Wan Liz Ozman and Sulzani studies another method of marketing (the additional marketing) in term of sales orientation (2002). SMEs focus on how to do a massive sales and promote the sustainable sales. In line with the purpose, promotion strategy aims to disseminate information about the supply of goods is very important. There are four tools or methods which considered to be the most appropriate promotion of the products for SME namely: advertising, sales promotion, personal selling and publicity. O'Regan and Ghobadian $(2004$, p. 292) argues that most of the scale businesses in the United States, are SMEs; therefore, there is a need to explore the role of marketing orientation in SMEs as a distinct group from the business organization. Spillan and Parnell (2006) in his research explains that there is a significant relationship between marketing orientation and performance of SMEs.

Jovanov, TM; Stojanovski (2012) explains that SMEs typically have certain characteristics, which serve to distinguish it from the larger business organization. These characteristics include the inherent weaknesses with respect to capitalization and awareness in marketing their products. High failure rate of SMEs is largely due to weaknesses in financial management and marketing. Marketing practices in the context of the characteristics of SMEs need to consider the role of the owner or managers in improving the company's marketing practices.

In small enterprises, the line between marketing and sales becomes difficult to be distinguished, because 
marketing occurs during the sales process and for many small companies, the owner or manager has the perception that selling is the marketing (Oakey, 1991, pp. 343-356).

Some marketing activities pose a particular problem for smaller enterprises. Research shows that a small company that does market research and efficiency promotion, has a difficulty in determining the measurement, while for the price of the product, they just rely on what is considered the industry norm, regardless of the company's own its' individual circumstances (Jovanov, 2011). Marketing activities in small enterprises has a direct correlation to the attitude of the owner or manager, experience, and expertise in marketing. A small enterprise owner or manager has a little time to think strategically about the business (Brown, 1995), with the limited resources that require intuitive decision making (Tibbits, 1981, pp. 173-188). Jovanov Marjanova Conevska (2011) concludes that the results of his marketing functions have several problems in term of poor cash flow, lack of marketing expertise, business size, as well as the tactical and strategic problem of customer relationships.

MSMEs needs to have marketing in a compatible setup with the characteristics of the company and accepted by the owner or manager. Most small enterprises, marketing theory offers little practical use in everyday marketing activities. Knowledge and skills in marketing can also be obtained through education.

Marketing educators need to establish what is required by the owners or managers in general about marketing, and also marketing education in particular, and how it can be delivered.

Another way to practice marketing in small business is through the use of a marketing tool, which offers a comprehensive and easiness through a guidance to assist SMEs in developing, implementing and managing their marketing efforts such as: Market Assessment, Plan Marketing, Branding, Public Relations, Advertising, Collateral marketing, Digital Marketing, Promotion, and Sales Leads.

Reijonen (2009) explains that traditionally, marketing theory has been developed on SMEs scale. In his dissertation research which concentrates on three interrelated constructions: marketing concept, market orientation and business success. The marketing concept is defined as organizations destination to identify the needs and wants of targeting markets and then to meet their needs more effectively and efficiently than its competitors. Market orientation is the implementation of the marketing concept. It consists of three behavioral components, namely customer orientation, competitor orientation, and inter-functional coordination and three sets of activities, such as generating, disseminating, and responding to market intelligence. Finally, market orientation seems to improve the company's performance and success.

Perception about SMEs marketing concept refers to the business philosophy (Kohli \& Jaworski, 1990). SMEs concentrates more on marketing tasks, such as promotions, and the ultimate goal of marketing is making a sale. Möller and Anttila (1987) also finds in the SME marketing is often viewed from the narrow perspective of sales orientation. Hill (2001) and Hogarth-Scott et al. (1996) states that one of the reasons that the company's survival often depends on the sales. The results showed that the customer has the important role to be studied in marketing SMEs. Creating and maintaining relationships with customers that are considered important and success is measured by customer satisfaction.

\section{Research Method}

This paper reviews marketing aspect specifications and government policy on SMEs in Indonesia by using qualitative and quantitative approach. The qualitative approach is used to describe the government policy in marketing according to Act no.20 year 2008 about SMEs and marketing strategy from Cooperation Ministry deputy and MSMEs in marketing. The quantitative approach is to describe the MSMEs performance towards the economy in Indonesia by analysing the Cooperation Ministry and MSMEs secondary data in 2010-2011 including enterprise unit growth, PDB data, employment and non-oil export data. The analysis results in government policy implementation toward the MSMEs development and empowerment in Indonesia. In a nut shell, analysis by using qualitative and quantitative approach is a conceptual frame approach and an empirical study on marketing aspect and government policy for MSMEs in Indonesia.

\section{The Government Policy Aims toward the Micro, Small, and Medium Enterprises (MSMEs)}

Small and Medium Enterprises has contributed to economic growth in some countries, therefore, the government assistance strongly supports to the increasing growth in the number of small and medium enterprises. Government assistance and intervention in the development and empowerment program of small and medium micro enterprises are realized with a wide range of policies at the central and local governments in the short, medium and long term development programs. Amizade, F. V. (2011) explains that the central and local governments as well as communities have an important role in promoting SMEs, so as to improve the 
development of a country. The government is responsible for shaping policy at the national level and enable the promotion of SMEs, contributing to employment, household incomes and poverty reduction. Kornijezuk (2004, p. 11) states that micro and small enterprises plays a relevant role in the use of raw materials, meet the needs of local markets, distribution of income and social mobility. In the globalization era, SMEs is key actors in any production system and contribute significantly to job creation and the formation of Gross Domestic Product.

Ayyagari et al. (2007) in his study identifies that SMEs as a core element in the strategy of the community to encourage economic growth, employment and poverty reduction. Rural development is rooted in the development of community-based and uses a bottom-up approach to improve the countryside communities through decentralization, participation, and governance (Behera \& Engel, 2006, p. 14). Jahanshahi et al. (2011) explains that the development of SMEs in India contribute to job creation, improve the income of the community, and also address the problem of regional disparities.

Government policy affects the level of entrepreneurial activity - regulatory policy, trade policy, labor market policy, regional development policy, social policy, and even the gender policy. It is the regular duty for the Government to encourage the growth of local MSMEs and it can help directly to reduce the poverty by increasing income levels and creating jobs. Policy with respect to the development of the field of marketing has been described in Law No. 20 of 2008 on MSMEs. The content of Law No. 20 of 2008, Article 18 is about the development in the field of marketing, as referred to in Article 16 paragraph (1) letter $b$ is done by: a. conducting marketing research and studies; $b$. disseminating market information; c. Improve management and marketing techniques; d. provides a means of marketing which includes the implementation of market testing, marketing agencies, trade house provision, and the promotion of Micro and Small Enterprises; e. provide support for the promotion of the products, network marketing, and distribution; and f. provide professional consultants in the field of marketing. Policies in this marketing field is also supported by Hadiyati (2010), her research results assert that the empowerment of MSMEs conducted by the central and local governments in the field of marketing, especially in the area of Trenggalek, Indonesia; the goverments provide the assistance in form of exhibitions, trade boards, trade missions and business meeting which is influential to sales. The more effective means of promotion of the government will be supporting the sales activities of the products of MSMEs.

Article 19, the development in the field of human resources as referred to in Article 16 paragraph (1) letter $\mathrm{c}$ is done by: a. promoting and cultivating entrepreneurship; b. improving the technical and managerial skills; and c. establishing and developing education and training institutions to undertake education, training, counseling, motivation and creativity of the business, and the creation of new entrepreneurs. Article 20 which is about the development in the field of design and technology refers to in Article 16 paragraph (1) letter d, the realization is done by: a. building capacity in the field of design and technology and quality control; b. promoting cooperation and transfer of technology; c. improving the ability of Small and Medium Enterprises in the field of research to develop new designs and technologies; d. providing incentives for Micro, Small and Medium Enterprises that develop technology and protect the environment; and e. encouraging the Micro, Small, and Medium Enterprise to obtain a certificate of intellectual property rights.

The implementation of empowerment programs for Micro, Small and Medium Enterprises in the future, requires the necessary adjustments and improvements to strategic activities or new initiative activities. Whether both activities that have not been accommodated but it has been coordinated through the Ministry of Cooperatives and Micro Small Medium Enterprise in outline of the Strategic Plan of the Ministry of Cooperatives and Micro Small and Medium Enterprises year 2010-2014. In the preparation of the Strategic Plan of the Ministry of Cooperatives and Micro Small and Medium Enterprises year 2010-2014 based on the Law No. 20 Year 2008 on Micro, Small and Medium Enterprises; the government encourages and accelerates the empowerment of Micro, Small and Medium Enterprises as well as improve competitiveness.

Specifically, in order to achieve optimum result, the Ministry of Cooperatives and MSMEs have established cooperatives and MSMEs empowerment strategies in the areas of marketing especially for the product development and marketing strategies. The improvement of MSME product in term of quality, innovation and creativity is a chain that requires considerable attention in the development of marketing and business networks of MSMEs. Coordination between production and marketing are absolutely necessary to direct the efforts to empower the integrated and sustainable SMEs; the empowerment includes the approach of the One Village One Product (OVOP). The purpose of the marketing and the strengthening of network is to win the domestic market share and an increase in the export market. Ministry of Cooperatives and SMEs has commissioned the Institute of Marketing Services for Micro Small and Medium Enterprises as an independent business unit, but it is still a unit under the Ministry to facilitate the promotion of Micro Small and Medium Business products in domestic and international markets. The scope of activities are the promotion of superior products, providing market 
information, and providing human resources and develop partnerships between MSMEs with large enterprises to carry out the functions of marketing and training for marketing product of Small and Medium Enterprises.

Ministry of Cooperatives and SMEs (2012) argues that the implementation of MSME development programs are technically involving institutional deputy in accordance with the field and its function, namely: Deputy Head of Marketing and Business Network. Details of the activities are as follows:

a. The development and expansion of export markets for Micro Small and Medium Enterprises, the programs are: (1) Provision of potential export market information for MSMEs products; (2) Strengthening the capacity and standardization, (3) Promotion of MSMEs potential export products; (4) MSMEs takes part in the overseas exhibitions; (5) facilitating to increase competitiveness ; (6) partnership to promote creative industries; (7) facilitating trading house; (8) Developing information systems for consolidation of MSME export cargo.

b. The development of MSMEs marketing Infrastructure, the programs are: (1) Facilitating the development of traditional markets, (2) Guidance on market management by the cooperative; (3) Development of MSMEs' marketing business facilities in the strategic locations and group; (4) Revitalization of Traditional Markets in remote or border areas (5) Market Revitalization Pilot through cooperatives; (6) revitalized marketing efforts; (7) facilitating the market access of Product MSME in strategic places (Commodities Market); (8) Supporting micro businesses through facilitating schools cooperative; (9) facilitating the micro enterprise through assistance in product registration; (10) Facilitating the Development of SMEs in the cosmetic products and traditional medicine sector.

c. Development of MSMEs through partnerships, the programs are; (1) Improving the product quality of MSMEs which is market-oriented; (2) Facilitating the organization of partners meeting activities; (3) Strengthening the institutional marketing of MSME products; (4) Facilitating MSMEs through partnership to improve product packaging; (5) Facilitating MSMEs through partnership to know the franchise system; (6) Facilitating MSMEs through the partnership to know the trading system; (7) Facilitating MSMEs through partnership to know subcontracts system; (8) Facilitating MSMEs through partnership to know about eco-products system; (9) Facilitating MSMEs facilitated through partnership in the tourism sector; (10) Facilitating MSMEs through partnership in the biomass energy sector; (11) Facilitating MSMEs through partnership with State-Owned Enterprises; (12) Facilitating MSMEs to be an investment partner to certain institution.

d. Development of product marketing network of MSMEs, the programs are; (1) Organizing the Street Vendors; (2) Increasing the productivity of MSMEs; (3) Developing of MSMEs business networks; (4) Facilitating the organization of the activity people market for the business expansion; (5) Improving the market access of MSMEs; (6) Facilitating micro business to develop into a business network of modern retail; (7) Facilitating micro business through the clinic; (8) Facilitating micro business through a public market; (9) Facilitating street Vendors to secure their business location; (10) Organizing the coordination of marketing programs and business networks.

e. Development of product promotion of MSMEs, the programs are; 1) Collecting the data and information relating to the products of MSMEs; (2) Facilitating the promotion of MSMEs market expansion in various forms, such as catalogs publications of Cooperatives and MSMEs product, promotion through the internet media, exhibition and cooperation with the Institute of Public Service Agency Marketing Services of the Ministry of Cooperatives and SMEs; (3) participating in the MSMEs exhibition (MSMEs Festival); (4) printing the MSMEs product catalog; (5) MSMEs participating in the thematic, creative and participatory exhibitions; (6) promotion of MSMEs through the MSMEs Trading Board .

\subsection{Definition and Criteria Micro, Small and Medium Enterprise (MSMEs)}

General limitations in this article defines MSMEs for industrial and non- industrial processing. For the definitions of MSMEs in the processing industry, following the Central Bureau of Statistics which is based on the amount of labor, are as follows:

- Micro business is the economic activity that is carried out either by individuals or households and a body, the number of the employee are 1-4.

- Small businesses are the economic activity that is carried out either by individuals or households and a body, the number of the employee are 5-19.

- Medium business is the economic activity that is carried out either by individuals or households and a body, the number of the employee are 20-99.

While the definition of MSMEs, following the definition of non-industrial, according to Law No. 20 of 2008 on 
MSMEs, are as follows:

- Micro business is the economic activity that is carried out either by an individual or household as well as a body that has a net assets up to IDR 50 million and aims to produce goods or services for commercial sale and has an annual sales turnover of up to IDR 300 million.

- Small businesses are the economic activities carried out either by an individual or household as well as a body that has a net assets up to IDR 50 million up to IDR 500 million and aims to produce goods or services for commercial sale and has an annual sales turnover up to IDR 300 million up to IDR 2.5 billion.

- Medium businesses is economic activity that is carried out either by individuals or households as well as a body that has net assets of up to IDR 500 million to IDR 10 billion and aims to produce goods or services to be sold commercially and have a turnover of sales annually until IDR 2,5 billion to IDR 50 billion.

\subsection{The Role of MSMEs toward Economy in Indonesia}

Empowerment of MSMEs is very strategic, because of its great potential in driving the economic activities, and also to be a basis for most of the sources of income of the people to improve their welfare. The existence and role of MSMEs which is in 2011 reached 55.21 million business units, and it covers 99.99 percent of businesses agent in nationwide, in the national economy system, it is not doubt that MSMEs has given many benefits such as its contribution to provide employment, the establishment of the National Gross Domestic Product (GDP), improve the foreign exchange, and national investment. The progress of empowerment of MSMEs from year to year, is always monitored and evaluated both in terms of its contribution to the creation of the gross domestic product (GDP), provision of employment, creation of national foreign exchange through exports, and development of business actors. Overall, the above macroeconomic indicators are always used as a reference in the development of policies to empower MSMEs as well as an indicator of the successful implementation of policies that have been implemented in the previous year. The role and contribution of MSMEs to the economy was based on data in 2010-2011, from the data it can be seen the development of MSMEs in terms of the creation of the GDP, the revenue of the value of non-oil exports and employment.

\subsection{The Progress of the Number of MSMEs}

Statistics of MSMEs (2012) describe the development of the number of micro, small, and medium enterprises in 2010-2011 period, the result is that the number of the MSMEs is increasing by 2.57 percent from $53,823,732$ units in 2010 to 55,206,444 units in 2011. From the data, it can be concluded that MSMEs are businesses with the largest percentage at 99,99 percent of businesses nationwide in 2011. For more details, the number of the data of MSMEs development can be seen in Figure 1.

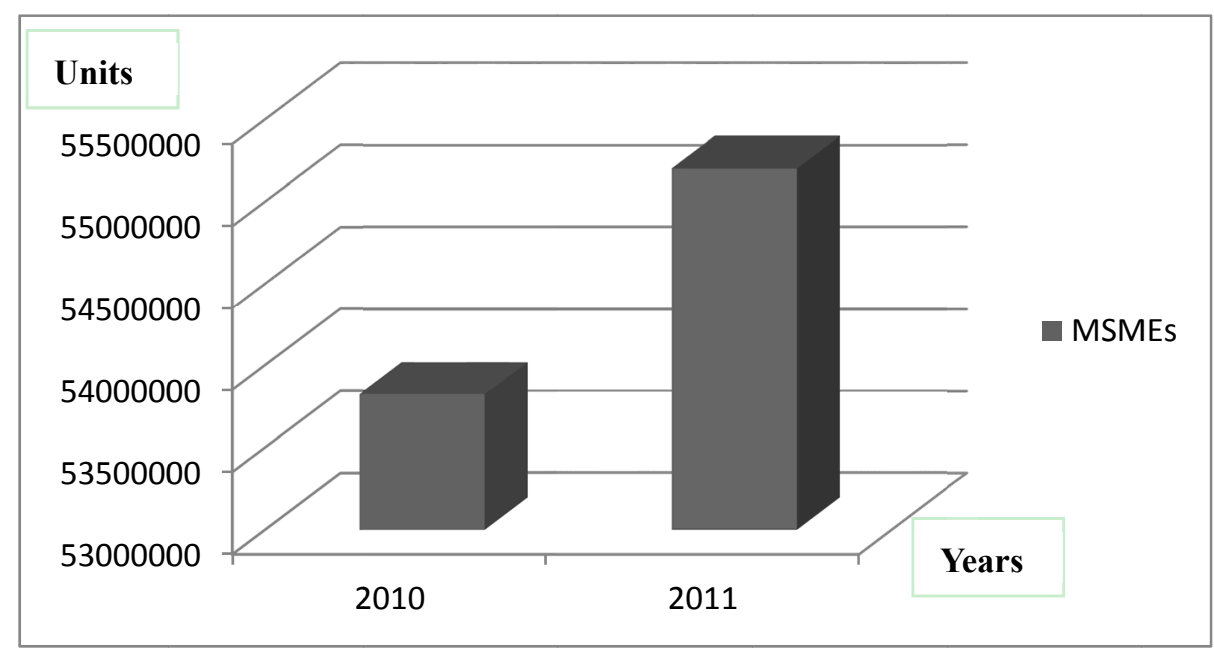

Figure 1. The number of MSMEs development in 2010-2011

From the data, the largest proportion of business units in MSMEs are (1) Agriculture, Livestock, Forestry and Fisheries (48.85 percent); (2) Trade, Hotels and Restaurants (28.83 percent); (3) Transportation and Communications (6.88 percent); (4) Manufacturing (6.41 percent); and (5) services (4.52 percent. While smallest proportion of business units in MSMEs are (1) Finance, Real Estate and Business Services (2.37 percent); (2) 
Building (1.57 percent); (3) Mining and Quarrying (0.53); and (4) Electricity, Gas and Water (0.03).

\subsection{MSMEs Contribution to the Creation of Gross Domestic Product (GDP)}

MSMEs Statistics (2012) explains the role of MSMEs in 2010 to the creation of the national GDP in current prices was IDR 3466.4 trillion or 57.12 per cent, the contribution of Micro enterprise was IDR 2051.9 billion or 33.81 percent and the Small Business was IDR 597.8 billion or 9.85 percent. While Medium Enterprises was IDR 816.7 trillion, or 13.46 percent of the total national GDP, the rest is large business, it was IDR 2602.4 trillion, or 42.88 percent. Whereas in 2011, the role of MSMEs to the creation of the national GDP in current prices was IDR 4303.6 trillion or 57.94 percent of the total national GDP, experiencing growth of IDR 837.2 trillion, or 24.15 percent compared to 2010. Contributions of Micro Enterprise was IDR 2579.4 billion or 34.73 per cent and the Small Enterprise was IDR 722.0 billion or 9.72 percent. While Medium Enterprise was IDR 1002.2 trillion or 13.49 per cent, large business was IDR 3123.5 billion or 42.06 per cent. For more details, the contribution of MSMEs to GDP based on current prices is in Figure 2.

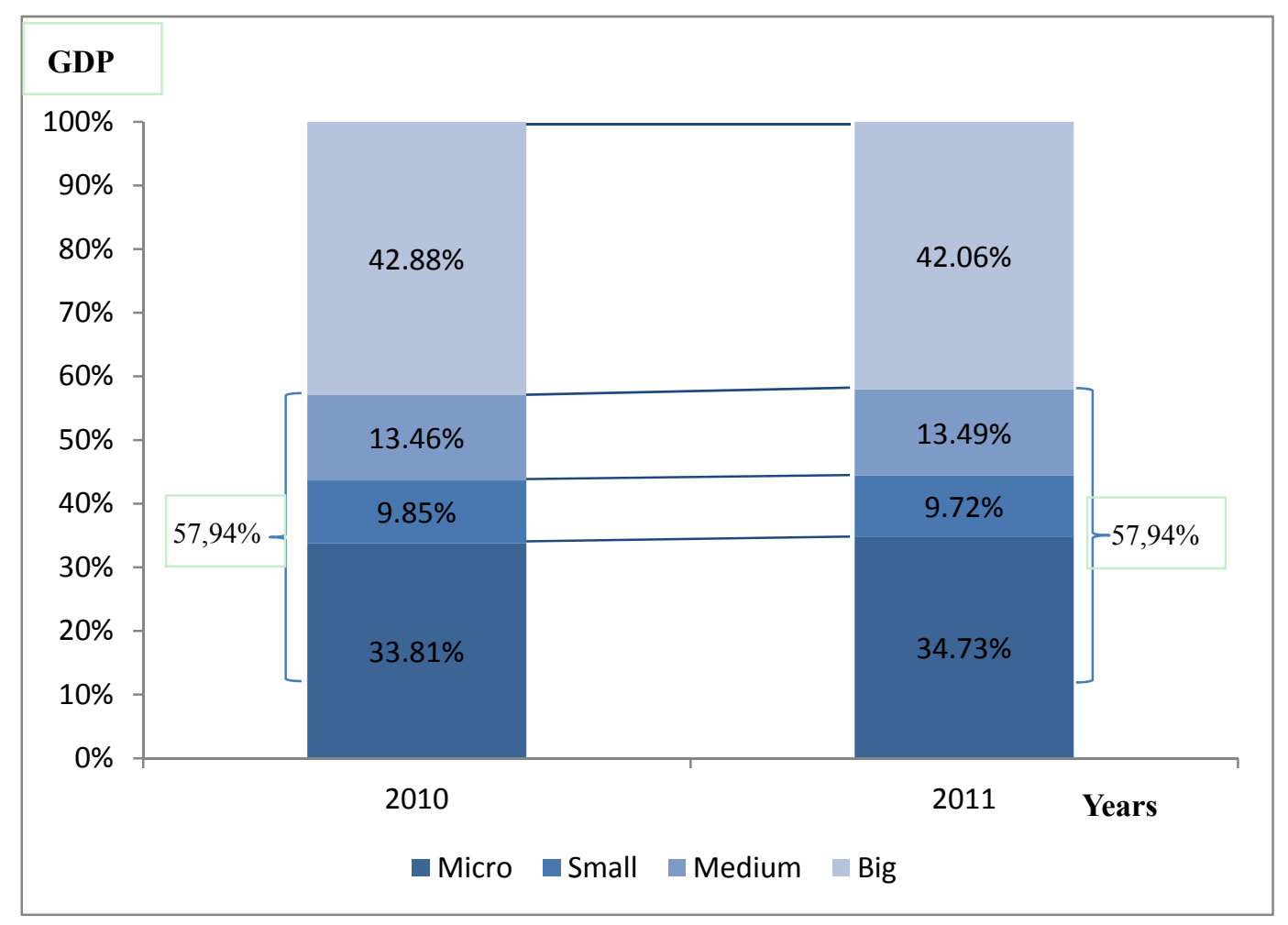

Figure 2. MSMEs contribution to GDP at current price in 2010-2011

On the other hand, in 2010 the value of the national GDP at constant price in 2000 is at IDR 2217.9 trillion, the role of SMEs is IDR 1282.6 trillion or 57.83 percent of the total GDP IDR 239.1 trillion, or 10.78 percent. While Medium Enterprises stood at IDR 324.4 trillion, or 14.63 percent, the rest is Large Business, it contributes IDR 935.4 trillion, or 42.17 percent. The contribution of micro and small enterprise nationally was IDR 719.1 billion or 32.42 percent, the national GDP at constant price in 2000 was IDR 2377.1 trillion, the contribution of MSMEs was IDR 1369.3 trillion or 57.60 percent (the contribution of Micro enterprise was IDR 761.2 trillion, or 32.02 per cent and the Small enterprise was IDR 261.3 trillion, or 10.99 percent and Medium Enterprise was 346.8 trillion or 14.59 percent), while the contribution of Large Enterprises was IDR 1007.8 trillion, or 42.40 percent. The contribution of MSMEs is increased by IDR 86.8 billion or 6.76 per cent over the previous year. For more details, the contribution of SMEs to GDP, based on constant prices is in Figure 3. 


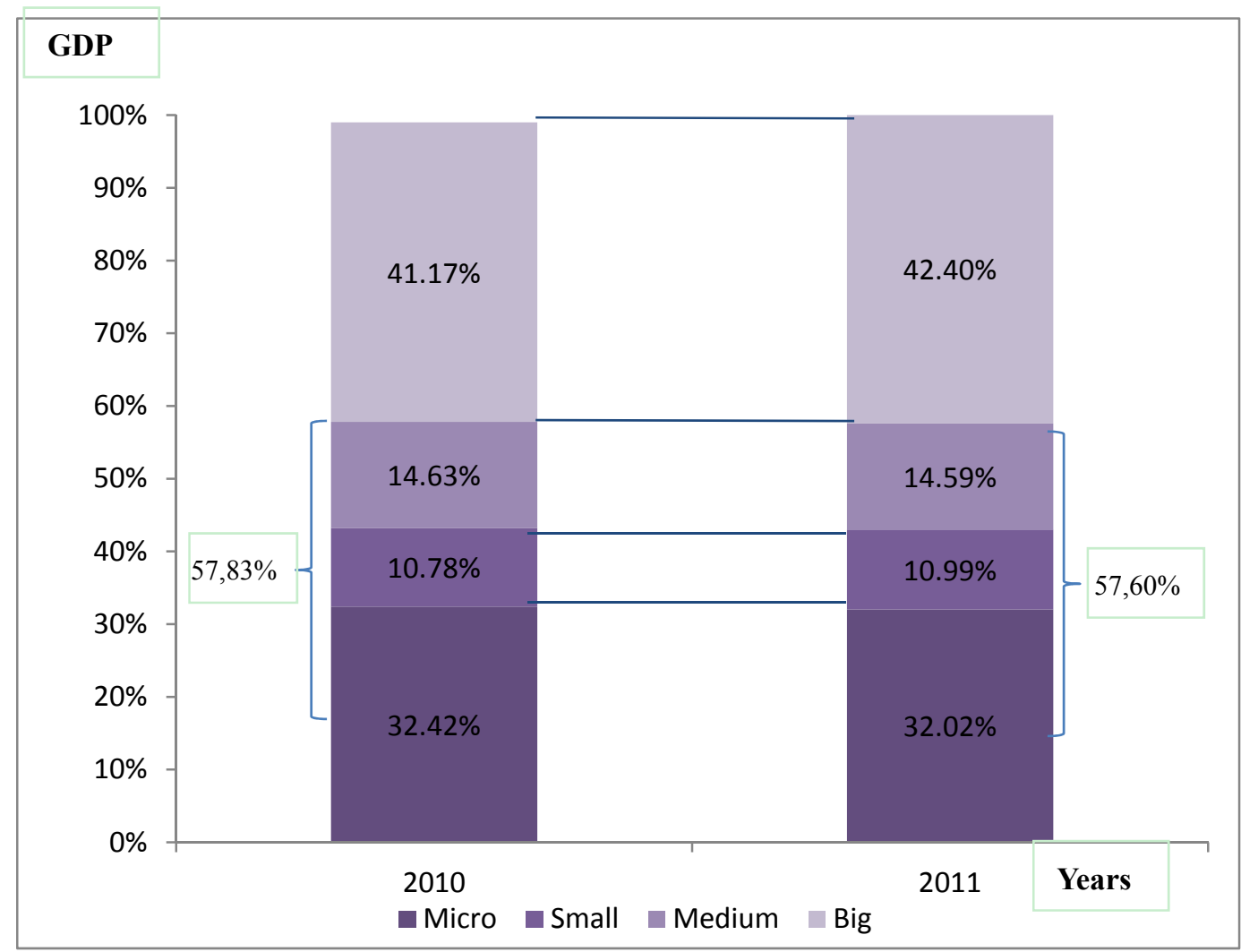

Figure 3. The contribution of MSMEs, based on GDP constant prices in 2010-2011

The MSMEs contribution Against the Total Establishment of Export Value.

MSMEs Statistics (2012) describes the contribution of MSMEs to the formation of the total value of non-oil exports in 2010 and the amount is IDR 175.9 trillion, or 15.81 percent. The contribution of Micro enterprise was IDR 16.7 billion or 1.50 percent and the Small enterprise is IDR 38.0 billion or 3.42 percent, while Medium enterprise is IDR 121.2 trillion, or 10.89 percent and the rest is Large Business, it contributes IDR 936.8 trillion, or 84.19 percent.

In 2011, the role of SMEs to the formation of the total value of non-oil exports was increased by IDR 11.5 billion or 6.56 percent. It means the MSMEs has achieve target achievement rate of IDR 187.4 trillion, or 16.44 percent of the total value of non-oil exports. The contributions Micro enterprise was Rp 17.2 billion or 1.51 percent and the Small enterprise was IDR 39.3 billion or 3.45 percent. While Medium Enterprises was IDR 130.9 trillion, or 11.48 per cent, Large Business contributed IDR 953.0 trillion or 83.56 percent. For more details SMEs contribution to the formation of export value is in Figure 4. 


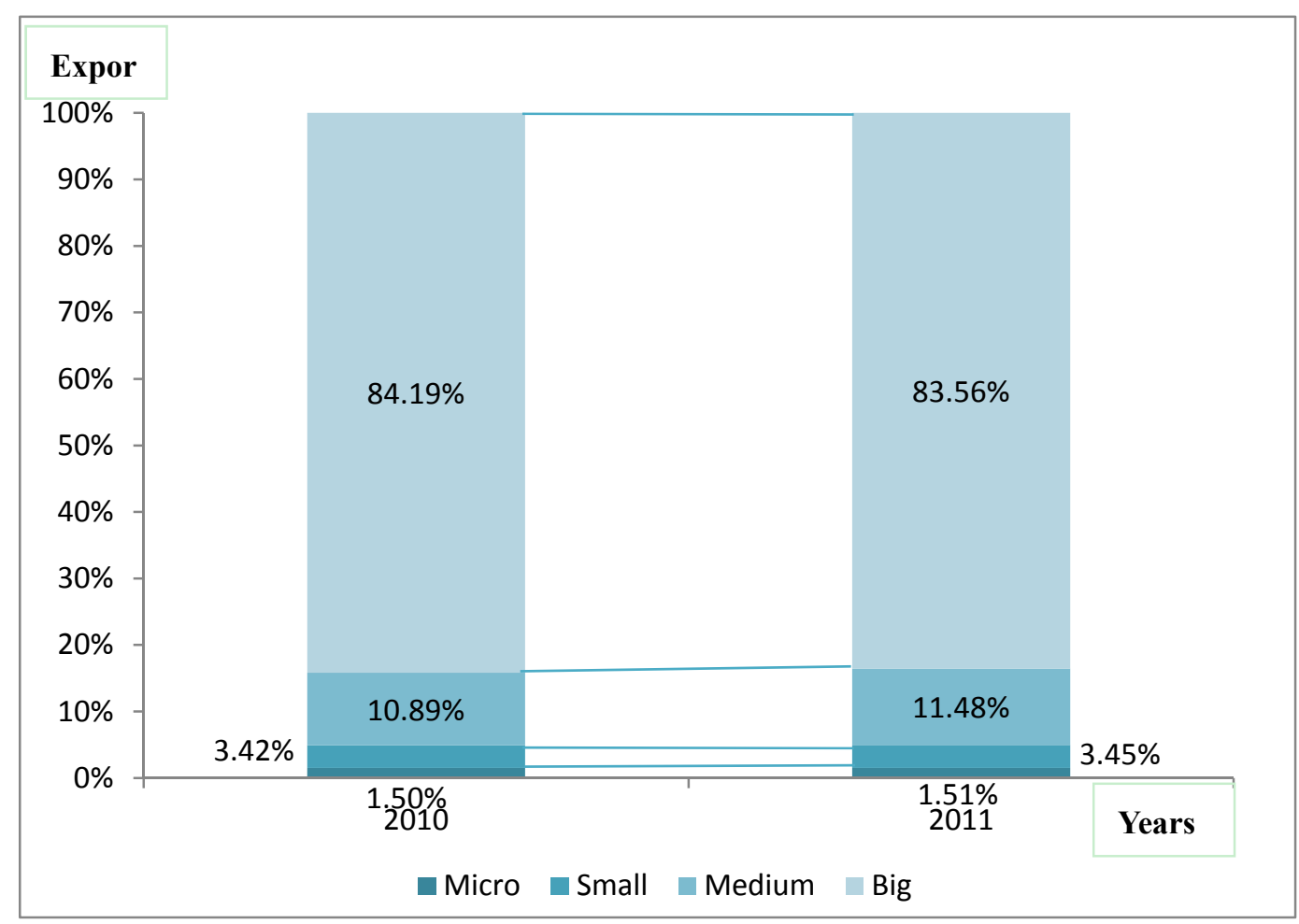

Figure 4. Contributions of MSMEs to the establishment of export value in 2010-2011

\subsection{Contribution of MSMEs in Generating Employment}

MSMEs Statistics (2012) describe the employment opportunities, and the role of MSMEs (2010) in generating employment was $99,401,775$ people, or 97.22 percent of the total provision of the existing labor force. The contribution of Micro Enterprise was 93,014,759 people or 90.98 percent, and small enterprises was 3,627,164 people, or 3.55 percent, Medium Enterprises was 2,759,852 people or 2.70 percent, and the rest is Large Business. In 2010, for Micro Enterprise on Agriculture, Livestock, Forestry and Fisheries have the largest role in employment because they can employ $42,262,866$ people, or 45.44 percent of the total labor force. While the largest employment in Small Business is in the Manufacturing sector, and it employs 986166 people or 27.19 percent. The same pattern applies to Medium Enterprises, the largest employment is in manufacturing sector, and it hires 1,240,694 people or 44.96 percent.

In 2011, MSMEs can create jobs for 101,722,458 people or 97.24 percent of the total provision of the existing labor force, this number was increased by 2.33 percent, or 2,320,683 people compared to 2010 . The contributions of Micro enterprise was 94.957 .797 or 90.77 percent, the Small enterprise was 3,919,992 people or 3.75 percent. While Medium Enterprises, there was 2,844,669 people, or 2.72 percent. The large proportion job provision of Micro enterprise are in agriculture, livestock, forestry and fisheries, the number was 42,543,128 people, or 44.80 percent of the total labor force. That number was increased by 280262 people or 0.66 percent from the previous year. For economic sectors that have the largest employment in Small Business is the Manufacturing sector, it employs 1,162,195 people or 29.65 percent. While the largest employment sectors on Medium Enterprises is the Manufacturing sector, it hires 1,231,298 people or 43.28 percent. For more details, the contribution of MSMEs to employment is in Figure 5. 


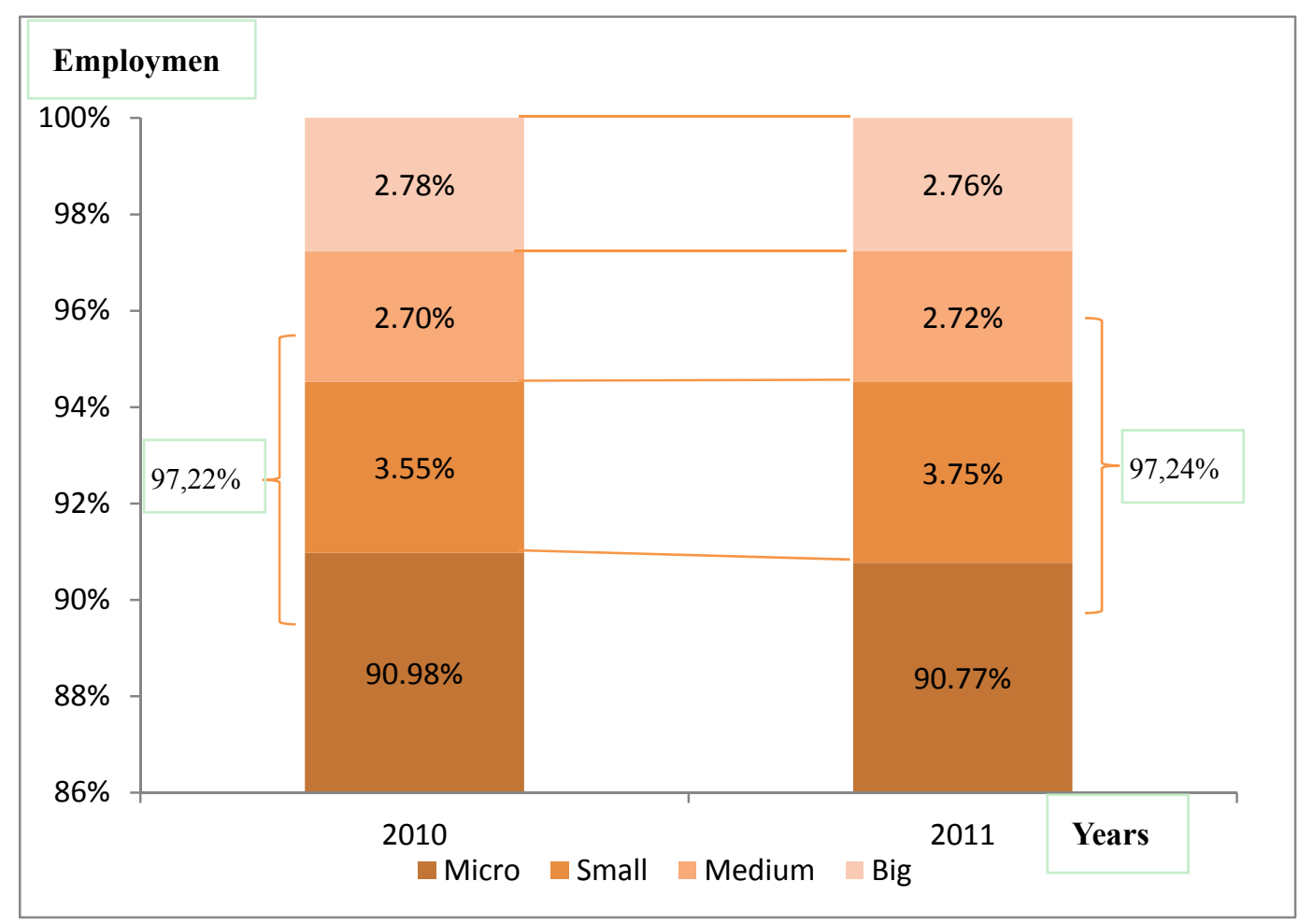

Figure 5. Contributions of MSMEs in generating employment in 2010-2011

\section{Discussion}

According to the previous data and explanation, SMEs has substantial contribution to the economy in Indonesia. Therefore, the government has an important role to the promotion and development of small enterprise. The government of United Kingdom of Great Britain and Northern Ireland (2012) has experienced the development of SMEs. They conduct promotion for SMEs in a simple and straightforward bureaucracy. This programs encourage SMEs to take advantage of government assistance that affect business performance. Souksavanh (2014) in his study of SMEs in Laos explains the government's role in promoting SME has no impact on the performance of the company. These findings imply the need for effective policies to promote SMEs with related policies, such as increasing the effectiveness of education, both formal education and vocational or technical training; improving the dissemination and enforcement of laws and regulations related to the business.

Liu, X. (2008) describes the small and medium enterprises (SMEs) in China has achieved rapid and sustained growth in the last two decades. The growth has been increasingly contributing to the economic development of China. SMEs that contribute to the economy in China already spot their problem. They have weak relationship with the external market, lack of technological innovation, and finance problem. This case brings to the needs for a more efficient government services and professionals for SMEs to enhance their competitiveness. The absence of high-quality services to the enterprise should encourage the government to provide SMEs with more professional service, convenient. So, SME can improve their ability to stay competitive in business. To implement this program, central and local governments need to coordinate the empowerment program.

\section{Conclusion}

In Indonesia, and many countries, MSMEs has high contribution, so it is important for the government to continue empowering and developing the enterprise. In conducting its business performance, MSMEs faces several problems, one of the problems encountered is the field of marketing. Problems in marketing requires government intervention in solving it. The Government can impose various policies at the central and regional as outlined in the form of law and government regulations to support the development of MSMEs. There are several ways to measure the success of the government's role in the empowerment of MSMEs. The success are the development of national and local economics performance through Gross Domestic Product and Gross Regional Domestic Product, generating employment and contributing to the revenue of non-oil exports. 


\section{References}

Amizade, F. V. (2011). The Role of Local Governments in Promoting SMEs: A Case of Rural Development in Monapo District. Final Report by Chacuamba, Ritsumeikan Asia Pacific University. Master of Sciences in International Cooperation Policy.

Abdullah. (1997). Pembangunan perindustrian di Malaysia perkembangan dan permasalahan. Shah Alam: Fajar Bakti Sdn. Bhd.

Ayyagari, M., \& Beck, T. (2007). A Small Business Economics, 29, 415-434.

Bell, C., \& Newby, H. (1972). Community studies: An introduction to the sociology of the local community. New York: Praeger Publishers.

Behera, \& Engel. (2006). A New Institutional Economics (NIE) Forest Policy and Economics. Institutional Analysis of Evolution of Joint Forest Management (JFM) in India, 8(4), 350-362.

Blankson, C., Motwani, J. G., \& Levenburg, N. M. (2006). Understanding the patterns of market orientation among small businesses. Marketing Intelligence \& Planning, 24(6), 572-590. http://dx.doi.org/10.1108/02634500610701663

Brown, J. (1995). Business Growth Action Kit. London: Kogan Page.

Chamhuri, S., \& Abdul, H. J. A. M. Z. (1995). Industri desa Semenanjung Malaysia. Bangi: Universiti Kebangsaan Malaysia.

Chee, P. L. (1985). The Role of Small Industry in Malaysia. PhD Thesis. Kuala Lumpur: Universiti.

Cromie, S. (1991). The Problems Experienced by Young Firms. International Small Business Journal, 9(3). http://dx.doi.org/10.1177/026624269100900303

Fillis, I. (2002). Small Firm Marketing Theory and Practice: Insights from the Outside. Journal of Research in Marketing \& Entrepreneurship, 4(2), 134-157. http://dx.doi.org/10.1108/14715200280001469

Gilmore, A., Carson, D., \& Grant, K. (2001). SME marketing in practice. Marketing Intelligence \& Planning, 19(1), 6-11. http://dx.doi.org/10.1108/02634500110363583

Hadiyati. (2009). Kemitraan UMKM. Teori dan Aplikasi Bantuan BUMN-Bank. Bayu Media Publishing. Malang, Indonesia.

Hadiyati, E. (2010). Efektifitas Promosi dan Penjualan Pada Usaha Kecil. Program Pascasarjana Universitas Wijaya Putra Surabaya, Jawa Timur Indonesia.

Hadiyati. (2010). Pemasaran Untuk UMKM. (Teori dan Aplikasi). Jilid 1. Bayu Media Publishing, Malang, Indonesia.

Hill, J. (2001). A multidimensional study of the key determinants of effective SME marketing activity: Part 2. International Journal of Entrepreneurial Behaviour \& Research, 7(6), 211-235. http://dx.doi.org/10.1108/EUM0000000006538

Hogarth-Scott, S., Watson, K., \& Wilson, N. (1996). Do small businesses have to practice marketing to survive and grow? Marketing Intelligence \& Planning, 14(1), 6-18. http://dx.doi.org/10.1108/02634509610106197

Jahanshahi et al. (2011). The Relationship between Government Policy and the Growth of Entrepreneurship in the Micro, Small \& Medium Enterprises of India. Journal of Technology Management \& Innovation, 6(1), 66-77. http://dx.doi.org/10.4067/S0718-27242011000100007

Jovanov, M. T. (2011). Market Orientation, Marketing Strategy and Plan - Basic Business Steps for Successful Competitive Positioning of the SMEs on the Market - With a Special Focus on the Confectionary Industry and Market in Republic of Macedonia. Doctoral Dissertation (working paper): Faculty of Economics.

Jovanov, T. M. (2012). Marketing Knowledge And Strategy For Smes: Can They Live. Retrieved from https://eprints.ugd.edu.mk

Conevska, B. (2011). Comparative Analysis of Factors From Marketing and Legal Perspective and Policies That Afect SMEs in Macedonia and EU, Conference Proceedings form the The First International Conference-Researching Economic Development And Enterpreneurship In Transitional Economies, Faculty of Economics, University of Banja Luka, Banja Luka, Bosnia and Herzegovina.

Kementrian Koperasi dan UMKM. (2012). Peraturan Menteri Negara Koperasi Dan Usaha Kecil Dan Menengah Republik Indonesia Nomor: 06 /Per/M.Kukm/Xi/2012. Tentang Rencana Startegis Kementerian Koperasi 
Dan Usaha Kecil Dan Menengah Tahun 2012-2014.

Kohli, A. K., \& Jaworski, B. J. (1990). Market Orientation: The Construct, Research Propositions, and Managerial Implications. Journal of Marketing, 54(2), 1-18. http://dx.doi.org/10.2307/1251866

Kornijezuk, F. B. S. (2004). Características empreendedoras de pequenos empresários de Brasília. Universidade de Brasília, Brasilia.

Liu, X. (2008). SME Development in China: A Policy Perspective on SME Industrial Clustering. In Lim, H. (Ed.), SME in Asia and Globalization, ERIA Research Project Report 2007-5 (pp. 37-68). Retrieved from http://www.eria.org/SME\%20Development\%20in\%20China_A\%20Policy\%20Perspective\%20on\%20SME \%20Industrial\%20Clustering.pdf

McCartan-Quinn, D., \& Carson, D. (2003). Issues which Impact upon Marketing in the Small Firm. Small Business Economics, 21(2), 201-231. http://dx.doi.org/10.1023/A:1025070107609

Möller, K., \& Anttila, M. (1987). Marketing Capability - A Key Success Factor in Small Business? Journal of Marketing Management, 3(2), 185-203. http://dx.doi.org/10.1080/0267257X.1987.9964038

Omar, A. (2014). The Marketing Of Small And Medium Enterprise (Sme) Products Based On Food Processing. European Journal of Business and Social Sciences, 3(5), 76-87.

Oakey, R. (1991). Innovation and the Management of Marketing in High Technology Small Firms. Journal of Marketing Management, 7(4) (October), 343-356. http://dx.doi.org/10.1080/0267257X.1991.9964163

O'Dwyer, M., Gilmore, A., \& Carson, D. (2009). Innovative marketing in SMEs. European Journal of Marketing, 43(1/2), 46-61. http://dx.doi.org/10.1108/03090560910923238

O'Regan, N., \& Ghobadian, A. (2004). The importance of capabilities for strategic direction and performance. Management Decision, 42, 292. http://dx.doi.org/10.1108/00251740410518525

Progress Report. (2012). Making Government business more accessible to SMEs-One Year On Progress report on enabling more SMEs to tender for government procurements March 2012 SME Progress Report. Retrieved from https://www.gov.uk/government/.../SME-Progress-Repo...

Reijonen. (2009). Role and Practices Of Marketing In SMEs. Thesis, Faculty of Law, Economics and Business Administration. The University of Eastern Finland is a university in Finland with three campuses in Joensuu, Kuopio, and Savonlinna. It was formed in 2010 by a merger of two previously independent universities. Retrieved

from http://epublications.uef.fi/pub/urn_isbn_978-952-219-306-3/urn_isbn_978-952-219-306-3.pdf.

Reynolds, P. L. (2002). The Need for a New Paradigm for Small Business Marketing? What is Wrong with the Old One? Journal of Research in Marketing \& Entrepreneurship, 4(3), 191-205. http://dx.doi.org/10.1108/14715200280001471

Souksavanh. (2014). Entrepreneurship, Government Policy and Performance of SMEs in Laos GSICS Working Paper Series No. 28 January 2014. Graduate School of International Cooperation Studies Kobe University.

Smith, D. (1990). Small is Beautiful, but Difficult: Towards Cost-Effective Research for Small Business. Journal of The Market Research Society, 32(1), 37-60.

Spillan Dan Parnell. (2006). Marketing Resources and Firm Performance among SMEs. European Management Journal, 24, 2-3.

Statistik UMKM. (2012). Statistik Usaha Mikro Kecil Menengah (2010-2011). Sekretaris Kementerian Negara. Retrieved

from http://www.depkop.go.id/index.php?option=com_phocadownload\&view=file\&id=344:statistik-ukm-2012\& Itemid $=9$

Stokes, D. (2000b). Putting Entrepreneurship into Marketing: The Processes of Entrepreneurial Marketing. Journal of Research in Marketing \& Entrepreneurship, 2(1), 1-16. http://dx.doi.org/10.1108/14715200080001536

Sulistiyono, D. M. (2010). Strategi Pengembangan Pemasaran Usaha Kecil Menengah (UMKM) Pengrajin Sepatu Sandal. Hasil Penelitian Peneliti Muda-Tahun 2010. Retrieved from http://mmulyana.wordpress.com

Tibbits, G. E. (1981). Small Business Management: A Normative Approach. In Peter, G., Philip, D., \& Peter, W. (Eds.), Small Business Perspectives, Chapter 5, Part 2 (pp. 173-188). London: Armstrong Publishing, 
London Business School,

Ugwushi, B. I. (2009). SMEs Key Failure-Factors: A Comparison between the United Kingdom and Nigeria. Journal of Social Sciences, 18(3), 204.

Watson, J. (2003). The Potential Impact of Accessing Advice on SME Failure Rates, Proceedings of the 16th Annual Conference of Small Enterprise Association of Australia and New Zealand, Ballarat.

\section{Copyrights}

Copyright for this article is retained by the author(s), with first publication rights granted to the journal.

This is an open-access article distributed under the terms and conditions of the Creative Commons Attribution license (http://creativecommons.org/licenses/by/3.0/). 